\title{
ANALISA KESUKSESAN SISTEM INFORMASI AKADEMIK (SIAKAD) DI PERGURUAN TINGGI DENGAN MENGGUNAKAN D \& M IS SUCCESS MODEL (STUDI KASUS: ITS SURABAYA)
}

\author{
Ardhini Warih Utami ${ }^{1)}$, Febriliyan Samopa ${ }^{2)}$ \\ ${ }^{1}$ Jurusan Teknik, Mesin Fakultas Teknik, Universitas Negeri Surabaya \\ Jalan Ketintang, Surabaya 60231 \\ Telp. : (031)-8280009, 8280393 Fax : (031)-8280804 \\ ${ }^{2}$ Jurusan Sistem Informasi, Fakultas Teknologi Informasi, Institut Teknologi Sepuluh Nopember \\ Kampus Keputih, Sukolilo, Surabaya 60111 \\ Telp: (031) 5999944, Fax: (031) 5964965 \\ ${ }^{1}$ E-mail: ardhinie_wrh21281@yahoo.com
}

\begin{abstract}
Implementation of academic information system in universities are used to process academic data. The purpose of this research is to measure and test the variables and indicators that influence the success of academic information system in universities with ITS as a case study. Adopting Delone \& Mclean IS Success research model, a set of structured questionnaires were distributed to 115 respondents who qualified as users (students, faculty, and staff employees). Test validity, reliability and outliers of the data was conducted to obtain valid and reliable data. The data were processed using Structural Equation Modeling (SEM). In this research, the variables used in this study include system quality, information quality, service quality, usage, user satisfaction and net benefits. The results has showed that in the first model there is significant positive correlation between: quality of the system, information quality and service quality. Service quality and user satisfaction also has a significant positive correlation on the use of academic information system. The use of information systems academic and academic information system user satisfaction has a significant positive effect on net benefits of academic information system. On the second model there is a relationship between variables, namely: system quality and service quality has a significant positive effect on the use of academic information system. System quality, information quality, service quality and the use of academic information system also has a significant positive effect on academic information system user satisfaction. Academic information system usage and user satisfaction of academic information system has positive and significant impact on the net benefits of academic information system. Based on the analysis, the success of academic information system at the ITS has a percentage of 62\%, which means the success of ITS academic information system at the level of "success", supported by the success factors generated in this study.
\end{abstract}

\section{Abstrak}

Implementasi sistem informasi akademik dalam lingkungan perguruan tinggi digunakan untuk pengolahan data akademik. Tujuan penelitian ini adalah mengukur dan menguji variabel-variabel serta indikator yang mempengaruhi kesuksesan sistem informasi akademik di penguruan tinggi dengan menggunakan perguruan tinggi ITS Surabaya sebagai studi kasus. Model penelitian yang dipergunakan mengadopsi model penelitian Delone \& Mclean IS Success. satu set kuesioner yang disusun dalam penelitian disebarkan kepada 115 responden yang memiliki kualifikasi sebagai pengguna sistem informasi akademik ITS (mahasiswa, dosen, staff karyawan). Uji validitas, reliabilitas dan outlier terhadap data penelitian dilakukan untuk memperoleh data yang valid dan reliabel. Selanjutnya data diolah dengan menggunakan Structural Equation Modelling. Pada penelitian ini terdapat 2 model penelitian, variabel yang dipergunakan dalam penelitian ini antara lain kualitas sistem, kualitas informasi, kualitas layanan, pemakaian, kepuasan pengguna dan manfaat-manfaat bersih. Hasil penelitian menunjukkan bahwa pada model 1 terdapat korelasi yang terjadi antar variabel yaitu kualitas sistem, kualitas informasi dan kualitas layanan memiliki pengaruh positif yang signifikan terhadap kepuasan pengguna sistem informasi akademik. Kualitas layanan dan kepuasan pengguna juga memiliki pengaruh positif yang signifikan terhadap pemakaian sistem informasi akademik, pemakaian sistem informasi akademik dan kepuasan pengguna sistem informasi akademik memiliki pengaruh positif yang signifikan terhadap manfaat-manfaat bersih sistem informasi akademik. Pada model 2 juga terdapat hubungan antarvariabel yaitu: Kualitas sistem dan kualitas layanan memiliki pengaruh positif yang 
Utami, dkk., Analisa Kesuksesan Sistem Informasi Akademik di Perguruan Tinggi dengan...

signifikan terhadap pemakaian sistem informasi akademik. Kualitas sistem, informasi, layanan dan pemakaian sistem informasi akademik juga memiliki pengaruh positif yang signifikan terhadap kepuasan pengguna sistem informasi akademik. Pemakaian sistem informasi akademik dan kepuasan pengguna sistem informasi akademik memiliki pengaruh postif dan signifikan terhadap terhadap manfaat-manfaat bersih sistem informasi akademik. Berdasarkan hasil analisa, kesuksesan sistem informasi akademik di ITS memiliki prosentase sebesar $62 \%$ yang artinya kesuksesan sistem informasi akademik ITS berada pada tingkatan "sukses" dengan didukung oleh faktor-faktor kesuksesan yang dihasilkan dalam penelitian.

Kata kunci: $\quad$ D \& M IS Success, sistem informasi akademik, pemodelan persamaan struktural

\section{PENDAHULUAN}

Perkembangan Sistem Informasi (SI) sekarang ini adalah faktor yang penting bagi sebuah perguruan tinggi untuk dapat bertahan hidup dan bersaing dalam dunia pendidikan. Tidak hanya itu, SI juga dapat meningkatkan efisiensi dan efektifitas bisnis akademik sehari-hari dengan cara integrasi proses bisnis dalam perguruan tinggi. Menurut Moertini (2008), perguruan tinggi sangat membutuhkan keberadaan sistem informasi yang didukung dengan TI dimana sistem informasi tersebut dapat memenuhi kebutuhan informasi dengan sangat cepat, tepat waktu, relevan, dan akurat.

Penggunaan sistem atau teknologi informasi dapat dijadikan sebagai salah satu komponen peningkatan mutu di perguruan tinggi. Hal ini terkait pada peningkatan kualitas akademik dan sebuah strategi unggul untuk mencapai keunggulan kompetitif sehingga perguruan tinggi dapat bersaing dengan perguruan tinggi yang lain dalam kancah pendidikan era global (Tanuwijaya dan Sarno (2010). Implementasi sistem informasi dalam lingkungan perguruan tinggi digunakan untuk pengolahan data akademik yang sering dikenal dengan sebutan Sistem Informasi Akademik (SIAKAD) (Suwanto, 2007). Kegagalan implementasi sistem informasi dan fenomena tambal sulam aplikasi sistem informasi ternyata juga dapat terjadi dalam SIAKAD, hal ini dapat dibuktikan dengan masih adanya perguruan tinggi yang telah melakukan pengembangan dan implementtasi SIAKAD lebih dari satu dekade lamanya, namun hasilnya belum memuaskan hingga saat ini (Suwanto dkk, 2007).

Sumadi (2010) mencatat sebanyak 92,5\% mahasiswa menyambut dengan baik dan merasa senang terhadap implementasi SIAKAD online dengan alasan sudah waktunya teknologi informasi diterapkan di perguruan tinggi. Selain itu juga terdapat alasan praktis karena dapat dilakukan dimana saja dan tidak harus menunggu dosen untuk administrasi akademik. Sebagian kecil (7,5\%) menyatakan kurang senang dengan alasan mereka masih mengalami kesulitan untuk mengakses dikarenakan jumlah komputer dan konektivitas internet yang masih terbatas.

Abugabah dan Sanzogni (2010) juga menemukan kurangnya fungsi sistem yang diterapkan terbukti menjadi salah satu faktor penyebab gagalnya implementasi sistem informasi pendidikan tinggi di Australia. Hal ini mendorong adanya suatu kebutuhan penting untuk melakukan evaluasi secara obyektif tentang keberhasilan atau kegagalan sistem yang berguna dalam mendukung pembuatan keputusan yang tepat. Penelitian yang telah dilakukan dalam meneliti faktor yang mempengaruhi kesuksesan implementasi sistem informasi adalah aspek perilaku dalam implementasi sistem informasi. Penelitian tersebut mencoba mempelajari perilaku individual dalam organisasi ketika menggunakan sistem informasi.

Jogiyanto (2007) mengelompokkan penelitian tersebut kedalam 2 aliran. Aliran yang pertama adalah aliran yang memiliki fokus penelitian pada penerimaan, adopsi, dan penggunaan dari sistem informasi. Beberapa teori dan model dari penelitian dalam kelompok yang antesedennya berupa suatu proses antara lain: model penyelesaian adaptasi pemakai (coping model of user adaptation) oleh Beaudry dan Pinsioneault (2005), partisipasi dan keterlibatan pemakai oleh Barki dan Hartwick (1994), dan model kesesuaian tugas-teknologi (task-technology fit) oleh Goodhue dan Thompson (1995).

Salah satu model yang populer dan berfokus pada kesuksesan implementasi di tingkat organisasi adalah model yang dikembangkan oleh Delone dan Mclean (1992) yang dikenal dengan Model Kesuksesan Sistem Informasi. Model ini memiliki ketergantungan dari enam pengukuran kesuksesan sistem informasi, yakni: kualitas sistem (system quality), kualitas informasi (information quality), kepuasaan pengguna (user statisfaction), penggunaan (use), dampak individu (individual impact), dan dampak organisasi (organizational impact). 
Penelitian ini dilakukan dengan tujuan mengukur kesuksesan SIAKAD di perguruan tinggi studi kasus pada implementasi SIAKAD yang diterapkan di ITS Surabaya. Untuk mengukur kesuksesan ini digunakan pendekatan model DeLone dan McLean: IS Success model. Model ini mengidentifikasi hubungan antar variabel sehingga dapat ditentukan faktor pendukung SIAKAD. Manfaat yang dapat diperoleh dari penelitian ini adalah rujukan bagi penyedia layanan SIAKAD maupun perguruan tinggi untuk mengevaluasi pelaksanaan sistem informasi dan memperbaiki kinerja penerapan SIAKAD. Selain itu, manfaat yang dapat dicapai adalah pengetahuan dan wawasan tentang pengukuran kesuksesan sistem informasi pada umumnya dan SIAKAD pada khususnya. Kontribusi penelitian ini adalah poin pengukuran dan kriteria kesuksesan dari tiap item pengukuran sistem informasi akademik (SIAKAD).

\section{METODOLOGI}

Metodologi yang digunakan untuk mengukur kesuksesan penerapan SIAKAD pada ITS Surabaya meliputi beberapa hal sebagai berikut

\subsection{Sistem Informasi Akademik (SIAKAD)}

Sistem Informasi Akademik (SIAKAD) menghimpun berbagai macam data yang dikelola dan diproses secara otomatis dengan alat dan metode tertentu. Sehingga SIAKAD akan menghasilkan informasi yang diperlukan agar terlaksananya kegiatan akademis dengan baik (Indrayani, 2011). Sistem ini dibagi ke dalam beberapa subsistem antara lain seleksi dan registrasi mahasiswa baru, kurikulum dan bidang studi, perkuliahan, tugas, ujian, pengelolaan dan pengembangan dosen, kelulusan, wisuda, alumni.

SIAKAD bagi ITS Surabaya merupakan media informasi, komunikasi dan proses manajemen yang memudahkan stakeholder dan civitas akademik ITS serta masyarakat luas untuk mengakses lebih mengetahui tentang ITS. Keberadaan SIAKAD ITS Surabaya menyederhanakan berbagai proses administrasi mahasiswa dalam bidang pendidikan, keuangan, serta akademik. Salah satu manfaat yang telah dirasakan adalah kemudahan dalam proses menyampaikan dan mendapatkan informasi akademik di ITS serta penghematan biaya yang dikeluarkan karena pemangkasan birokrasi yang panjang dan penghematan dari sisi jumlah SDM dalam penanganannya.

\subsection{Model Kesuksesan Sistem Informasi}

Konsep kesuksesan sistem informasi merupakan suatu konsep yang digunakan dalam berbagai riset sebagai kriteria dasar untuk mengevaluasi sistem informasi (Rai dkk, 2002). Kerangka pikir teoritis Delone dan Mclean (1992) dikenal dengan Delone \& Mclean Model of Information System Success (D\&M IS Success). Delone dan Mclean menjelaskan taksonomi mengenai enam variabel yang menjadi dasar pengukuran keberhasilan sistem informasi seperti yang nampak pada Gambar 1.

\subsection{Pengukur Kesuksesan Sistem Informasi}

Menurut model kesuksesan sistem informasi Delone dan Mclean (1992), kesuksesan sistem informasi dapat diukur dengan mengukur manfaat bersih yang didapatkan berdasarkan dua dimensi. Dua dimensi tersebut adalah dimensi kualitas (kualitas informasi, kualitas sistem dan kualitas layanan), dan dimensi pemakaian (use/intention to use) serta kepuasan pengguna. Delone dan Mclean menemukan bahwa kualitas sistem dan informasi memiliki pengaruh langsung pada kepuasan pengguna sistem informasi. Gambar 1 dan Tabel 1 mengilustrasikan variabel dan indikator pengukur kesuksesan sistem informasi yang digunakan dalam penelitian ini.

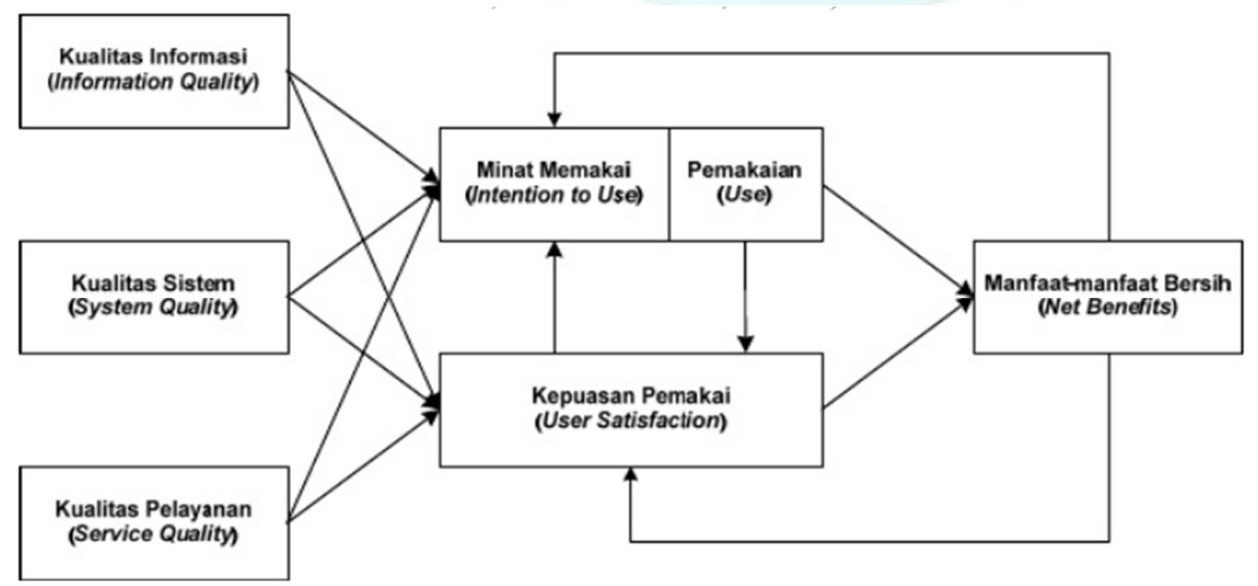

Gambarl. D \& M IS Success Model (Sumber : Delone,Mclean, 2003) 
Utami, dkk., Analisa Kesuksesan Sistem Informasi Akademik di Perguruan Tinggi dengan...

Tabel 1. Variabel dan Indikator Pengukur Kesuksesan SIAKAD

\begin{tabular}{|c|c|c|c|}
\hline Variabel & Indikator & Poin Pengukuran & Sumber \\
\hline \multirow{8}{*}{$\begin{array}{l}\text { Kualitas } \\
\text { Sistem } \\
\text { SIAKAD }\end{array}$} & \multirow{3}{*}{$\begin{array}{l}\text { Fungsionalitas } \\
\text { SIAKAD }\end{array}$} & Kegunaan/Fungsi (KSIST1) & Wilkin, 2003 \\
\hline & & & Wangpipatwong, 2005 \\
\hline & & Keamanan (KSIST2) & Molla dan Licker, 2001 \\
\hline & Kehandalan & Performansi Sistem (KSIST3) & Wilkin, 2003 \\
\hline & SIAKAD & & Wangpipatwong, 2005 \\
\hline & $\begin{array}{l}\text { Kegunaan } \\
\text { SIAKAD }\end{array}$ & Kemudahan Penggunaan (KSIST4) & Wilkin, 2003 \\
\hline & & Jarak Akses (KSIST5) & \\
\hline & $\begin{array}{l}\text { Aksesibilitas } \\
\text { SIAKAD }\end{array}$ & $\begin{array}{l}\text { SIAKAD Kompatibel dengan semua } \\
\text { peramban dan peralatan teknologi gadget } \\
\text { (KSIST6) }\end{array}$ & $\begin{array}{l}\text { Yang, dkk, } 2005 \\
\text { Negash, } 2003\end{array}$ \\
\hline \multirow{4}{*}{$\begin{array}{l}\text { Kualitas } \\
\text { Informasi } \\
\text { SIAKAD }\end{array}$} & Tingkat informatif & Kemampuan $\quad$ SIAKAD & \\
\hline & SIAKAD & memberikan informasi (KINF1) & \\
\hline & Relevansi & $\begin{array}{l}\text { Informasi SIAKAD memberikan manfaat } \\
\text { kepada penggunanya (KINF2) }\end{array}$ & \\
\hline & Ketepatwaktuan & Informasi SIAKAD tepat waktu (KINF3) & \\
\hline \multirow{4}{*}{$\begin{array}{l}\text { Kualitas } \\
\text { Layanan } \\
\text { SIAKAD }\end{array}$} & $\begin{array}{l}\text { Kehandalan } \\
\text { Layanan }\end{array}$ & $\begin{array}{lcc}\text { Kemampuan } & \text { SIAKAD } & \text { dalam } \\
\text { memberikan pelayanan (KLAY1) } & \end{array}$ & \multirow{4}{*}{$\begin{array}{l}\text { Parasuraman, dkk, } 1985 \\
\text { Kettinger dan Lee, } 1997\end{array}$} \\
\hline & Respon & $\begin{array}{l}\text { Sikap tanggap staff terhadap keluhan } \\
\text { layanan SIAKAD (KLAY2) }\end{array}$ & \\
\hline & Jaminan & $\begin{array}{l}\text { Jaminan layanan yang diberikan SIAKAD } \\
\text { (KLAY3) }\end{array}$ & \\
\hline & Empati & $\begin{array}{l}\text { Layanan SIAKAD mengenai kebutuhan } \\
\text { pengguna (KLAY4) }\end{array}$ & \\
\hline \multirow{4}{*}{$\begin{array}{l}\text { Pemakaian } \\
\text { SIAKAD }\end{array}$} & Frekuensi & Jumlah kekerapan pemakaian SIAKAD & \multirow{3}{*}{ Davis, 1989} \\
\hline & SIAKAD & (PEMK1) & \\
\hline & Durasi Waktu & Lama pemakaian SIAKAD (PEMK2) & \\
\hline & $\begin{array}{l}\text { Penggunaan nyata } \\
\text { SIAKAD }\end{array}$ & $\begin{array}{l}\text { Penggunaan SIAKAD oleh pengguna } \\
\text { (PEMK3) }\end{array}$ & Jogiyanto, 2007 \\
\hline \multirow{3}{*}{$\begin{array}{l}\text { Kepuasan } \\
\text { Pengguna } \\
\text { SIAKAD }\end{array}$} & Akurasi & Nilai Akurasi SIAKAD (KPENGG1) & \multirow{3}{*}{$\begin{array}{l}\text { Doll dan Torkzadeh, } \\
1988\end{array}$} \\
\hline & Konten & $\begin{array}{l}\text { Kelengkapan isi dari modul SIAKAD } \\
\text { (KPENGG2) }\end{array}$ & \\
\hline & Format & $\begin{array}{l}\text { Format penyajian informasi oleh } \\
\text { SIAKAD (KPENGG3) }\end{array}$ & \\
\hline $\begin{array}{l}\text { Manfaat } \\
\text { SIAKAD }\end{array}$ & $\begin{array}{l}\text { Dampak pada } \\
\text { individu } \\
\text { Dampak pada } \\
\text { organisasi }\end{array}$ & $\begin{array}{l}\text { Peningkatan produktivitas kinerja } \\
\text { individu (MB1) } \\
\text { Efektivitas dalam organisasi (MB2) }\end{array}$ & $\begin{array}{l}\text { DeLone dan McLean, } \\
2003\end{array}$ \\
\hline
\end{tabular}

\subsection{Analytical Hierarchy Process}

Metode AHP dikembangkan oleh Thomas L. Saaty, Metode ini adalah sebuah kerangka untuk mengambil keputusan dengan efektif atas persoalan yang kompleks dengan menyederhanakan dan mempercepat proses pengambilan keputusan dengan memecahkan persoalan tersebut kedalam bagian-bagiannya, menata bagian atau variabel ini dalam suatu susunan hirarki, memberi nilai numerik pada pertimbangan subjektif tentang pentingnya tiap variabel dan mensintesis berbagai pertimbangan ini untuk menetapkan variabel yang mana yang memiliki prioritas paling tinggi dan bertindak untuk mempengaruhi hasil pada situasi tersebut. Metode AHP ini membantu memecahkan persoalan yang kompleks dengan menstruktur suatu hirarki kriteria, pihak yang berkepentingan, hasil dan dengan menarik berbagai pertimbangan guna mengembangkan bobot atau prioritas. Dalam penyusunan skala kepentingan, Saaty menggunakan patokan pada tabel 2. 
Tabel 2. Skala Kepentingan Dalam AHP

\begin{tabular}{|c|c|c|}
\hline Skala & Definisi & Penjelasan \\
\hline 1 & Kedua elemen sama penting & $\begin{array}{l}\text { Dua elemen menyumbang sama besar pada sifat } \\
\text { tersebut. }\end{array}$ \\
\hline 3 & $\begin{array}{l}\text { Suatu elemen sedikit lebih penting } \\
\text { dibanding elemen yang lain. }\end{array}$ & $\begin{array}{l}\text { Pengalaman dan pertimbangan sedikit lebih } \\
\text { menyokong satu elemen disbanding elemen yang } \\
\text { lain. }\end{array}$ \\
\hline 5 & $\begin{array}{l}\text { Suatu elemen esensial dibanding } \\
\text { elemen yang lain. }\end{array}$ & $\begin{array}{l}\text { Pengalaman dan pertimbangan dengan kuat } \\
\text { menyokong satu elemen dibanding elemen yang } \\
\text { lain. }\end{array}$ \\
\hline 7 & $\begin{array}{l}\text { Suatu elemen jelas lebih penting } \\
\text { dibanding elemen yang lain. }\end{array}$ & $\begin{array}{l}\text { Satu elemen dengan kuat telah disokong dan } \\
\text { dominasinya telah terlihat dalam praktik. }\end{array}$ \\
\hline 9 & $\begin{array}{l}\text { Suatu elemen mutlak lebih penting } \\
\text { disbanding elemen yang lain. }\end{array}$ & $\begin{array}{l}\text { Bukti yang menyokong elemen yang satu atas yang } \\
\text { lain memiliki tingkat penegasan tertinggi yang } \\
\text { mungkin menguatkan. }\end{array}$ \\
\hline $2,4,6,8$ & $\begin{array}{l}\text { Nilai-nilai diantara dua pertimbangan } \\
\text { yang berdekatan }\end{array}$ & Kompromi diperlukan antara dua pertimbangan \\
\hline Kebalikan & $\begin{array}{l}\text { Aktivitas i mendapat satu angka bila } \\
\text { dibandingkan dengan aktivitas j, maka } \\
\text { j mempunyai nilai kebalikannya bila } \\
\text { dibandingkan dengan aktivitas i. }\end{array}$ & \\
\hline
\end{tabular}

\section{HASIL dan PEMBAHASAN}

Pada bab ini akan dituliskan hasil dari penelitian ini yaitu item dan elemen pengukuran serta kriteria kesuksesan implementasi SIAKAD di universitas.

\subsection{Poin Pengukuran, Elemen Pengukuran dan Kriteria Kesuksesan}

Poin pengukuran yang digunakan dalam penelitian ini tersaji pada Tabel 1. Poin dan elemen ini didapatkan dari hasil penyebaran kuesioner (terbuka-tertutup) serta dari analisis proses bisnis akademik. Poin pengukuran yang tidak memerlukan pembobotan (KSIST1, KSIST2, KSIST3, KSIST4, KSIST5, KSIST6, KINF1, KINF2, KINF3, KLAY1, KLAY2, KLAY3, KLAY4, PEMK1, PEMK2, PEMK3, KPENGG1, KPENGG3, MB1 dan MB2) terdiri dari elemen pengukuran yang tidak memerlukan prioritas. Hal ini dilihat dari tingkat kepentingan elemen satu dengan yang lain dalam satu item. Pembobotan untuk elemen pengukuran yang dilakukan dengan menentukan prosentase kesuksesan dengan formula (1).

$$
\frac{\text { Jumlah elemen yang dipilih }}{\text { Total elemen dalam } 1 \text { item }} \times 100 \%
$$

Poin pengukuran yang memerlukan pembobotan dalam hal ini item pengukuran KPENGG2 terdiri dari sejumlah modul yang dalam pemilihan elemen pengukuran tersebut membutuhkan bobot sebagai pertimbangan. Sebagai contoh modul FRS yang mempunyai tingkat kepentingan untuk diprioritaskan dalam SIAKAD sesuai dengan fungsinya yaitu memudahkan penyusunan mata kuliah yang diambil oleh mahasiswa untuk tiap semesternya. Pembobotan dilakukan dengan menentukan tingkat kepentingan menggunakan metode AHP. Pembobotan dilakukan oleh Dosen, staf layanan akademik dan mahasiswa. Formula 2 adalah penentuan persentase kesuksesan untuk elemen pengukuran yang memerlukan pembobotan

\section{Total bobot elemen yang dipilih $\times 100 \%$}

Tingkatan kesuksesan dari item pengukuran terhadap elemen yang dipilih pada tiap item pengukuran mengadopsi tingkatan kesuksesan yang dihasilkan oleh Purwanto (2007). Tabel 3 menunjukkan tingkat kesuksesan item pengukuran

Tabel 3. Tabel Tingkatan Kesuksesan (Sumber: Purwanto, 2007)

\begin{tabular}{|c|c|c|}
\hline Tingkat & $\begin{array}{c}\% \\
\text { Kesuksesan }\end{array}$ & Makna \\
\hline 1 & $0-20 \%$ & $\begin{array}{l}\text { Sangat Tidak Sukses } \\
\text { (STS) }\end{array}$ \\
\hline 2 & $21-40 \%$ & Tidak Sukses (TS) \\
\hline 3 & $41-60 \%$ & Cukup Sukses (CS) \\
\hline 4 & $61-80 \%$ & Sukses (S) \\
\hline 5 & $81-100 \%$ & Sangat Sukses (SS) \\
\hline
\end{tabular}


Utami, dkk., Analisa Kesuksesan Sistem Informasi Akademik di Perguruan Tinggi dengan...

Kriteria kesuksesan berdasarkan range persentase kesuksesan pada Tabel 3 adalah sebagai berikut:

- Apabila 1 elemen yang terpilih maka prosentasenya adalah $(1 / 5) \mathrm{X} 100 \%=20 \%$ $\rightarrow$ kriteria sangat tidak sukses.

- Apabila 2 elemen yang terpilih maka prosentasenya adalah $(2 / 5) \times 100 \%=40 \%$ $\rightarrow$ kriteria tidak sukses.

- Apabila 3 elemen yang terpilih maka prosentasenya adalah $(3 / 5) \times 100 \%=60 \%$ $\rightarrow$ kriteria cukup sukses.

- Apabila 4 elemen yang terpilih maka prosentasenya adalah (4/5) X 100\% $=80 \%$ $\rightarrow$ kriteria sukses.

- Apabila 5 elemen yang terpilih maka prosentasenya adalah $(5 / 5) \times 100 \%=100 \%$ $\rightarrow$ kriteria sangat sukses.

Enam variabel yang digunakan antara lain kualitas sistem, kualitas informasi, kualitas layanan, pemakaian, kepuasan pengguna dan manfaat bersih yang diadopsi dari penelitian Delone dan Mclean (2003). Model riset menunjukkan bahwa kualitas sistem, kualitas informasi dan kualitas layanan mempengaruhi pemakaian dan kepuasan pengguna. Pemakaian mempengaruhi kepuasan pengguna, kepuasan pengguna juga mempengaruhi pemakaian. Pemakaian dan kepuasan pengguna mempengaruhi manfaat bersih. Sehingga terbentuklah model riset yang diilustrasikan oleh Gambar 2.

Berikut adalah hipotesa yang akan dijawab dan diuji dalam penelitian ini:

H1a : Kualitas sistem SIAKAD berpengaruh positif terhadap pemakaian SIAKAD.

H1b : Kualitas sistem SIAKAD berpengaruh positif terhadap kepuasaan pengguna.

$\mathrm{H} 2 \mathrm{a}$ : Kualitas informasi SIAKAD berpengaruh positif terhadap pemakaian SIAKAD

$\mathrm{H} 2 \mathrm{~b}$ : Kualitas informasi SIAKAD berpengaruh positif terhadap kepuasaan pengguna.

H3a : Kualitas pelayanan SIAKAD berpengaruh positif terhadap minat pemakaian SIAKAD

$\mathrm{H} 3 \mathrm{~b}$ : Kualitas pelayanan SIAKAD berpengaruh positif terhadap kepuasaan pengguna

H4a : Pemakaian SIAKAD berpengaruh positif terhadap kepuasan pengguna SIAKAD.

H4b : Pemakaian SIAKAD berpengaruh positif terhadap manfaat bersih.

H5a : Kepuasan pengguna SIAKAD berpengaruh positif terhadap pemakaian SIAKAD.

H5b : Kepuasan pengguna SIAKAD berpengaruh positif terhadap manfaat bersih.

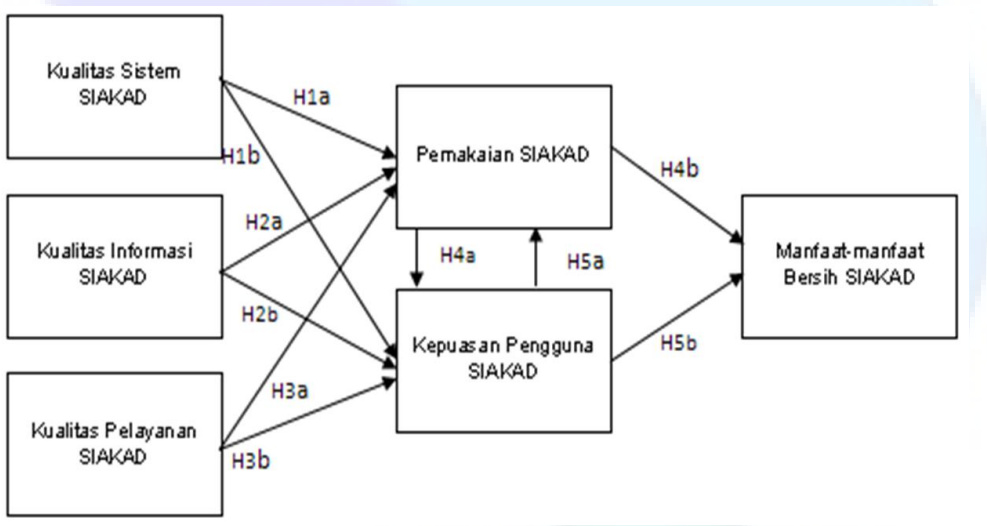

Gambar 2. Model Riset

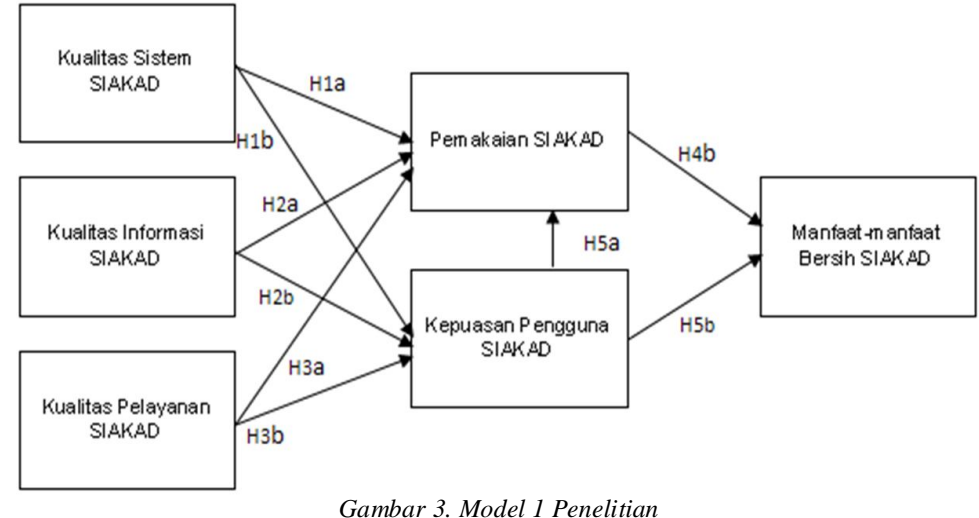




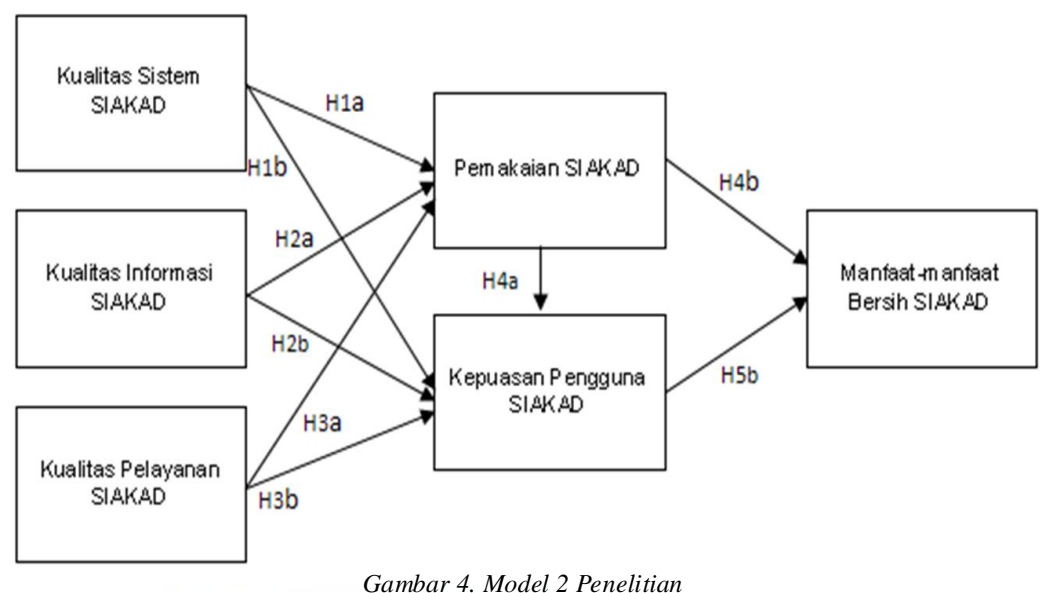

Model riset pada Gambar 2 menunjukkan dua arah antara pemakaian SIAKAD dengan kepuasan pengguna SIAKAD. Pengaruh mutual seperti ini tidak dapat diuji secara bersamaan, oleh karena itu harus diuji dua kali yaitu model 1 seperti pada Gambar 3 yang mengasumsikan pengaruh dari pemakaian SIAKAD ke kepuasan pengguna SIAKAD (H4a) dan model 2 seperti pada Gambar 4 yang mengasumsikan pengaruh dari kepuasan pengguna SIAKAD ke pemakaian SIAKAD (H5a).

\subsection{Instrumen Penelitian}

Penelitian kesuksesan SIAKAD di perguruan tinggi ini bersifat studi empiris yaitu berupa riset dilapangan yang bertujuan untuk mengumpulkan data dari responden. Untuk mendapatkan data dari responden, maka pengumpulan data dilakukan dengan survei menggunakan instrument penelitian berupa kuesioner. Instrumen penelitian (kuesioner) ini digunakan untuk mengukur nilai variabel yang diteliti (Sugiyono,2009). Kuesioner yang dijadikan sebagai instrumen dalam penelitian ini dilakukan dengan dua cara. Cara pertama dilakukan dalam tahap penelitian pendahuluan dengan tujuan untuk mendapatkan faktor-faktor kesuksesan SIAKAD di perguruan tinggi sebagai elemen pengukuran SIAKAD dengan sifat terbuka dan tertutup. Kuesioner kedua adalah kuesioner yang digunakan untuk menjawab hipotesa penelitian. Responden dibolehkan untuk memilih jawaban lebih dari satu pada tiap item pertanyaan. Setelah kuesioner ini diisi oleh responden, selanjutnya kuesioner tersebut akan dilakukan proses skala pengukuran. Skala pengukuran yang digunakan dalam penelitian ini adalah rating scale. Responden diminta untuk memberi centang pada kotak nomor jawaban yang tersedia terhadap sebagian besar pernyataan yang diajukan atas dasar persepsi masing-masing responden. Interval jawaban terdiri dari lima angka pilihan dimulai dari angka 1 sampai dengan angka 5 . Tabel 3 menunjukkan pemberian nilai (scoring) dari model skala rating scale yang dipergunakan dalam penelitian. Instrumen kuesioner dapat dilihat pada Lampiran.

\subsection{Uji Validitas dan Reliabilitas}

Validasi item pengukuran dalam kuesioner penelitian ini dilakukan dengan menggunakan bantuan software SPSS. Uji validitas dilakukan dengan menggunakan metode corrected item total correlation. Tabel 4 menunjukkan hasil pengujian validitas kuesioner menggunakan corrected item total correlation pada masingmasing item pengukuran.

Tabel 4 menunjukkan corrected item total correlation melebihi angka 0,30 maka dapat disimpulkan bahwa semua item pengukuran pada kuesioner dapat digunakan untuk mengukur kesuksesan SIAKAD. Sedangkan nilai cronbach's alpha yang melebihi angka 0,60 menunjukkan bahwa data hasil kuesioner reliabel untuk pengukuran kesuksesan SIAKAD.

\subsection{Uji Data Pencilan}

Data pencilan adalah data yang memiliki karakteristik unik yang sangat berbeda dari observasi - observasi lainnya. Biasanya data pencilan ini muncul dalam bentuk nilai ekstrim baik untuk variabel tunggal atau variabel kombinasi (Hair dkk dalam Ferdinand, 2002). 
Utami, dkk., Analisa Kesuksesan Sistem Informasi Akademik di Perguruan Tinggi dengan...

Tabel 4. Uji Validitas dan Reliabilitas

\begin{tabular}{lll}
\hline Indikator & $\begin{array}{l}\text { Corrected } \\
\text { Item-Total } \\
\text { Correlation }\end{array}$ & $\begin{array}{l}\text { Alpha } \\
\text { Cronbach's }\end{array}$ \\
\hline KSIST1 & 0,311 & \\
KSIST2 & 0,304 & \\
KSIST3 & 0,650 & 0,701 \\
KSIST4 & 0,534 & \\
KSIST5 & 0,478 & \\
KSIST6 & 0,362 & \\
\hline KINF1 & 0,529 & 0,603 \\
KINF2 & 0,439 & \\
KINF3 & 0,305 & \\
\hline KLAY1 & 0,683 & 0,836 \\
KLAY2 & 0,698 & \\
KLAY3 & 0,720 & \\
KLAY4 & 0,577 & 0,664 \\
\hline PEMK1 & 0,708 & \\
PEMK2 & 0,670 & 0,803 \\
PEMK3 & 0,351 & \\
\hline KPENGG1 & 0,594 & \\
KPENGG2 & 0,711 & \\
KPENGG3 & 0,655 & \\
\hline MB1 & 0,509 & \\
MB2 & 0,509 & \\
\hline & & \\
\hline
\end{tabular}

Analisis data pencilan dilakukan dengan dua cara yaitu analisis untuk data tunggal dan data berganda. Apabila ditemukan data pencilan maka tersebut harus dikeluarkan untuk proses selanjutnya. Berdasarkan hasil uji data pencilan tunggal, ada indikator yang memiliki nilai Zscore yang melebihi batas \pm 3 yaitu MB2. Sedangkan, jumlah observasi yang dikategorikan sebagai data pencilan tunggal dan dihilangkan yaitu responden ke-82.

Dari hasil uji data pencilan berganda, data responden 74 dan 107 memiliki nilai mahalonobis distance melebihi 46,80. Maka data tersebut harus dihilangkan sebelum melakukan analisis ke tahap berikutnya dengan jumlah responden menjadi 110 orang.

\subsection{Pengolahan dan Pengujian Data}

Data kuesioner yang telah diuji data pencilan selanjutnya dimasukkan ke dalam rancangan model pada SmartPLS. Model ini meliputi model pengukuran dan model struktural. Hasil kalkulasi dua model tersebut dapat dilihat pada gambar 3 dan gambar 4. Hasil kalkulasi tersebut dianalisa apakah semua indikator pada model mempunyai loading factor $>0.5$, jika tidak maka indikator tersebut harus dikeluarkan dari model (Chin, 1998 dalam Yamin \& Kurniawan (2011). Melalui uji ini, indikator KSIST1 dan KSIST2 adalah tidak valid dan harus dikeluarkan dari model.

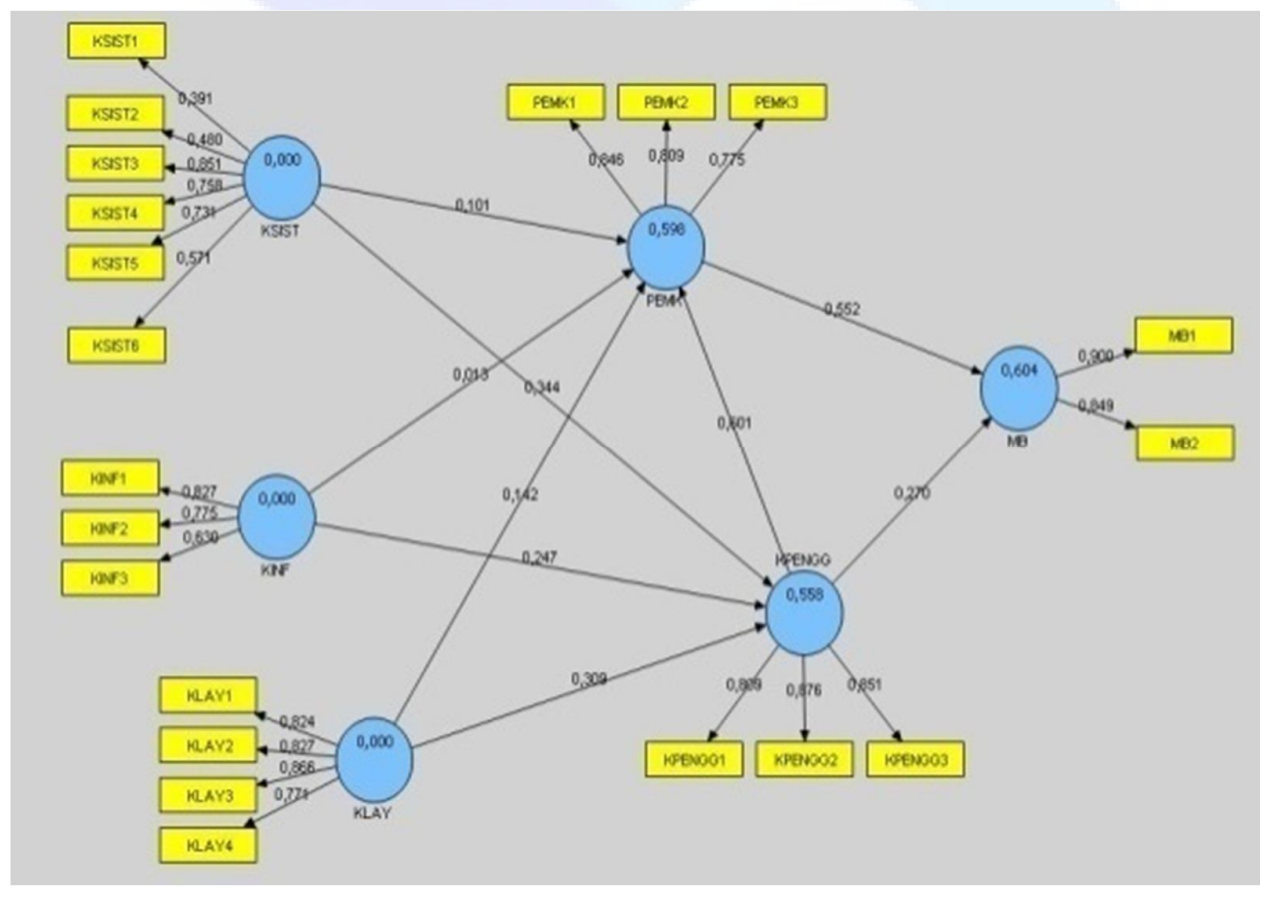

Gambar 3. Hasil Kalkulasi Terhadap Model 1 
Utami, dkk., Analisa Kesuksesan Sistem Informasi Akademik di Perguruan Tinggi dengan...

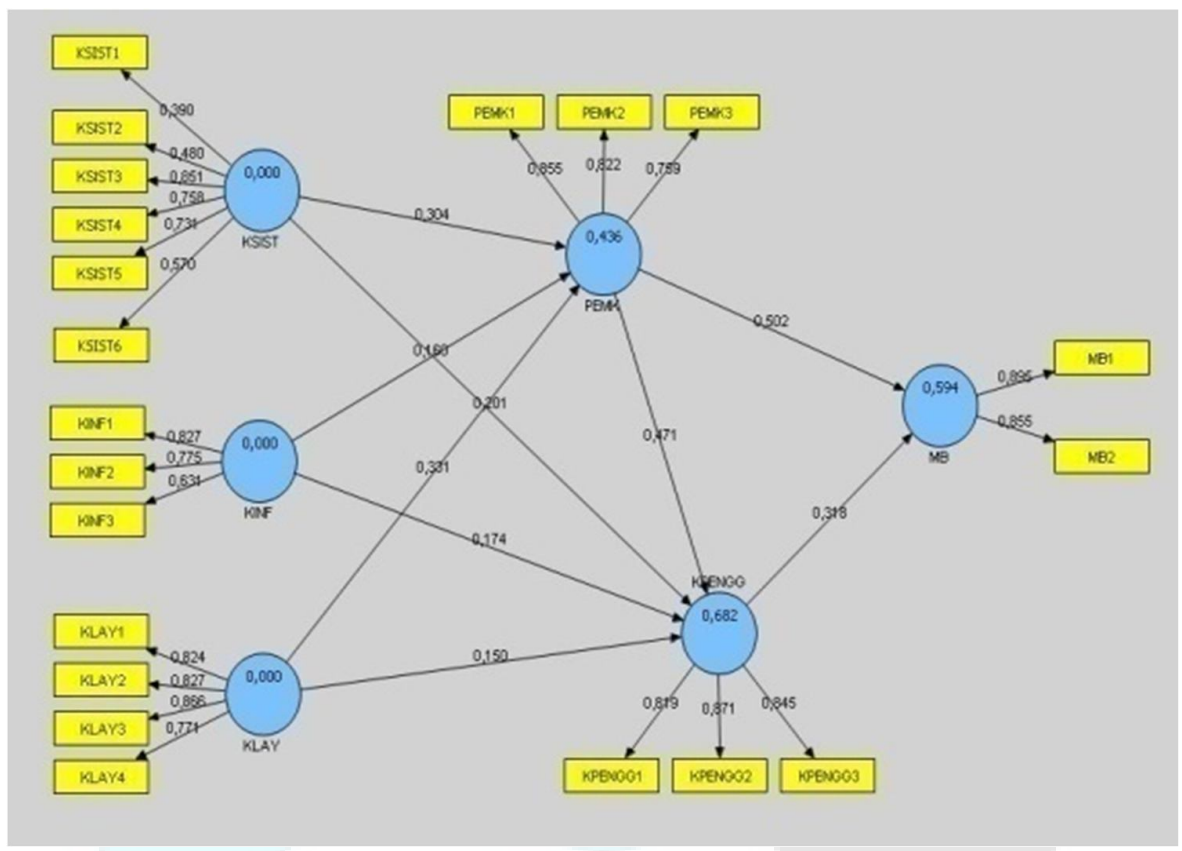

Gambar 4. Hasil Kalkulasi Terhadap Model 2

Tabel 4. Nilai Faktor Loading \& T-Statistic

\begin{tabular}{|c|c|c|c|c|}
\hline \multirow{2}{*}{ Hubungan indikator Variabel Latennya } & \multicolumn{2}{|c|}{ Iterasi 1} & \multicolumn{2}{|c|}{ Iterasi 2} \\
\hline & Model 1 & Model 2 & Model 1 & Model 2 \\
\hline \multicolumn{5}{|l|}{ Variabel Kualitas Sistem (KSIST) } \\
\hline KSIST1 $\leftarrow$ KSIST & 0.391 & - & 0.930 & - \\
\hline KSIST $2 \leftarrow$ KSIST & 0.480 & - & 0.480 & - \\
\hline KSIST3 $\leftarrow$ KSIST & 0.851 & 0.873 & 0.851 & 0.873 \\
\hline KSIST4 $\leftarrow$ KSIST & 0.758 & 0.768 & 0.758 & 0.768 \\
\hline KSIST5 $\leftarrow$ KSIST & 0.731 & 0.760 & 0.731 & 0.760 \\
\hline KSIST6 $\leftarrow$ KSIST & 0.571 & 0.585 & 0.570 & 0.595 \\
\hline \multicolumn{5}{|l|}{ Variabel Kualitas Informasi (KINF) } \\
\hline $\mathrm{KINF} 1 \leftarrow \mathrm{KINF}$ & 0.827 & 0.827 & 0.827 & 0.827 \\
\hline $\mathrm{KINF} 2 \leftarrow \mathrm{KINF}$ & 0.775 & 0.776 & 0.775 & 0.775 \\
\hline KINF3 $\leftarrow$ KINF & 0.630 & 0.630 & 0.631 & 0.631 \\
\hline \multicolumn{5}{|l|}{ Variabel Kualitas Layanan (KLAY) } \\
\hline KLAY1 $\leftarrow$ KLAY & 0.824 & 0.824 & 0.824 & 0.824 \\
\hline KLAY2 $\leftarrow$ KLAY & 0.827 & 0.827 & 0.827 & 0.827 \\
\hline KLAY $3 \leftarrow$ KLAY & 0.866 & 0.866 & 0.866 & 0.866 \\
\hline KLAY4 $\leftarrow$ KLAY & 0.771 & 0.770 & 0.771 & 0.771 \\
\hline \multicolumn{5}{|l|}{ Variabel Pemakaian Nyata (PEMK) } \\
\hline PEMK1 $\leftarrow$ PEMK & 0.846 & 0.847 & 0.855 & 0.856 \\
\hline PEMK $2 \leftarrow$ PEMK & 0.809 & 0.810 & 0.822 & 0.823 \\
\hline PEMK3 $\leftarrow$ PEMK & 0.775 & 0.773 & 0.759 & 0.757 \\
\hline \multicolumn{5}{|l|}{ Variabel Kepuasan Pengguna (KPENGG) } \\
\hline KPENGG1 $\leftarrow$ KPENGG & 0.889 & 0.888 & 0.819 & 0.818 \\
\hline KPENGG2 $\leftarrow$ KPENGG & 0.876 & 0.877 & 0.871 & 0.871 \\
\hline KPENGG3 $\leftarrow$ KPENGG & 0.851 & 0.851 & 0.845 & 0.846 \\
\hline \multicolumn{5}{|l|}{ Variabel Manfaat Bersih (MB) } \\
\hline $\mathrm{MB} 1 \leftarrow \mathrm{MB}$ & 0.900 & 0.900 & 0.895 & 0.895 \\
\hline $\mathrm{MB} 2 \leftarrow \mathrm{MB}$ & 0.849 & 0.849 & 0.855 & 0.856 \\
\hline
\end{tabular}


Utami, dkk., Analisa Kesuksesan Sistem Informasi Akademik di Perguruan Tinggi dengan...

Kemudian model dikalkulasi ulang, dan hasilnya menunjukkan semua indikator telah valid (lihat tabel 4). Hasil kalkulasi ulang tersebut kemudian diuji model pengukuran, model struktural, dan model keseluruhan (gabungan) untuk memperoleh hasil penelitian yang valid dan reliabel.

\subsection{Pengujian Model Pengukuran}

Model pengukuran (outer model) merupakan pola hubungan antara indikator dengan variabel yang diukurnya. Untuk menguji validitas dan reliabilitas. Model pengukuran adalah dengan melihat nilai loading factor $>0,5$ dan nilai tstatistic $\geq 1,96$, nilai composite reliability (CR) atau nilai cronbach's alpha $(\mathrm{CA})>0,7$ dan nilai Average Variance Extracted (AVE) $>0,5$. Nilai cronbach's alpha $=0,6$ dianggap cukup baik (Hair dkk dalam Vinzi dkk, 2010).

Pengujian terhadap model pengukuran berikutnya adalah melihat nilai cross loading factor bahwa setiap indikator yang mengukur variabel latennya harus berkorelasi lebih tinggi dengan variabel latennya dibanding dengan variabel laten lainnya, serta membandingkan nilai akar AVE dengan korelasi antar variabel latennya (Yamin \& Kurniawan, 2011). Nilai CR,CA dan AVE yang dihasilkan dalam penelitian ini ditampilkan dalam Tabel 5 dan Tabel 6.

Pada Tabel 5 menunjukkan nilai CA untuk semua variabel $\geq 0,6$ dan nilai $C R \geq 0,7$ hal ini menunjukkan bahwa model yang dipergunakan dalam pengukuran kesuksesan SIAKAD (didalamnya terdapat variabel beserta item /indikator dan elemen pengukuran yang digunakan dalam penelitian ini adalah reliabel oleh karenanya itu dapat diandalkan untuk mengukur/mengevaluasi kesuksesan SIAKAD.
Tabel 5. Nilai CR dan CA

\begin{tabular}{lcccc}
\hline \multirow{2}{*}{ Variabel } & \multicolumn{2}{c}{ Composite } & \multicolumn{2}{c}{ Cronbach's } \\
& Reliability (CR) & \multicolumn{2}{c}{ Alpha (CA) } \\
\cline { 2 - 5 } & $\begin{array}{c}\text { Model } \\
\text { Kodel }\end{array}$ & Model & Model \\
& 1 & 2 & 1 & 2 \\
\hline KINF & 0.790 & 0.790 & 0.599 & 0.599 \\
KLAY & 0.893 & 0.893 & 0.840 & 0.840 \\
KSIST & 0.839 & 0.839 & 0.741 & 0.741 \\
MB & 0.867 & 0.867 & 0.696 & 0.696 \\
PEMK & 0.851 & 0.853 & 0.746 & 0.745 \\
\hline
\end{tabular}

Tabel 6. Nilai AVE

\begin{tabular}{llc}
\hline \multicolumn{1}{c}{ Variabel } & \multicolumn{2}{c}{ AVE } \\
& \multicolumn{1}{c}{ Model 1 } & Model 2 \\
\hline KINF & 0.56 & 0.56 \\
KLAY & 0.67 & 0.67 \\
KPENGG & 0.71 & 0.71 \\
KSIST & 0.57 & 0.57 \\
MB & 0.76 & 0.76 \\
PEMK & 0.76 & 0.76 \\
\hline
\end{tabular}

Tabel 6 menunjukkan nilai AVE untuk semua variabel lebih dari 0,5 yang artinya variabel tersebut memiliki convergent validity yang baik apabila nilai AVE diatas 0,5 semakin tinggi nilai AVE berarti varian atau keragaman indikator yang dikandung semakin tinggi.

\subsection{Model Struktural}

Model struktural (inner model) merupakan pola hubungan antarvariabel penelitian. Evaluasi terhadap model struktural adalah dengan melihat koefisien hubungan antarvariabel dan nilai koefisien determinasi $\left(\mathrm{R}^{2}\right)$. Nilai $\mathrm{R}^{2}$ mendekati 1, dengan kriteria batasan nilai dibagi dalam 3 klasifikasi yaitu $0,67=$ subtansial, 0,33 = moderat, dan 0,19= lemah (Chin, 1998 dalam Yamin \& Kurniawan, 2011).

Tabel 7. Nilai Koefisien Jalur \& T-Statistic

\begin{tabular}{lllll}
\hline Hipotesis & Model 1 & & \\
Penelitian & Hubungan Antar Variabel & Koefisien Jalur & T-Statistic & Kesimpulan \\
\hline H1a & KSIST $\rightarrow$ PEMK & 0.081019 & 0.992 & Tidak Signifikan \\
H1b & KSIST $\rightarrow$ KPENGG & 0.330850 & 3.669 & Signifikan \\
H2a & KINF $\rightarrow$ PEMK & 0.018023 & 0.191 & Tidak Signifikan \\
H2b & KINF $\rightarrow$ KPENGG & 0.252601 & 2.666 & Signifikan \\
H3a & KLAY $\rightarrow$ PEMK & 0.142278 & 2.137 & Signifikan \\
H3b & KLAY $\rightarrow$ KPENGG & 0.313706 & 3.474 & Signifikan \\
H4b & PEMK $\rightarrow$ MB & 0.550752 & 8.190 & Signifikan \\
H5a & KPENGG $\rightarrow$ PEMK & 0.611865 & 7.382 & Signifikan \\
H5b & KPENGG $\rightarrow$ MB & 0.270248 & 3.086 & Signifikan \\
\hline
\end{tabular}




\begin{tabular}{|c|c|c|c|c|}
\hline \multicolumn{5}{|c|}{ Model 2} \\
\hline $\begin{array}{l}\text { Hipotesis } \\
\text { Penelitian }\end{array}$ & Hubungan Antar Variabel & Koefisien Jalur & T-Statistic & Kesimpulan \\
\hline H1a & KSIST $\rightarrow$ PEMK & 0.280000 & 3.041 & Signifikan \\
\hline $\mathrm{H} 1 \mathrm{~b}$ & KSIST $\rightarrow$ KPENGG & 0.196036 & 2.398 & Signifikan \\
\hline $\mathrm{H} 2 \mathrm{a}$ & $\mathrm{KINF} \rightarrow \mathrm{PEMK}$ & 0.170554 & 1.584 & Tidak Signifikan \\
\hline $\mathrm{H} 2 \mathrm{~b}$ & $\mathrm{KINF} \rightarrow \mathrm{KPENGG}$ & 0.173949 & 2.142 & Signifikan \\
\hline $\mathrm{H} 3 \mathrm{a}$ & KLAY $\rightarrow$ PEMK & 0.337239 & 3.851 & Signifikan \\
\hline $\mathrm{H} 3 \mathrm{~b}$ & KLAY $\rightarrow$ KPENGG & 0.150294 & 2.170 & Signifikan \\
\hline $\mathrm{H} 4 \mathrm{a}$ & PEMK $\rightarrow$ KPENGG & 0.477442 & 5.742 & Signifikan \\
\hline $\mathrm{H} 4 \mathrm{~b}$ & $\mathrm{PEMK} \rightarrow \mathrm{MB}$ & 0.499133 & 6.681 & Signifikan \\
\hline $\mathrm{H} 5 \mathrm{~b}$ & KPENGG $\rightarrow$ MB & 0.319021 & 3.958 & Signifikan \\
\hline
\end{tabular}

Tabel 8. Nilai R Square

\begin{tabular}{lll}
\hline \multirow{2}{*}{ Variabel Endogen } & \multicolumn{2}{c}{ R-Square } \\
MPENG 1 & Model 2 \\
MB & 0.55 & 0.68 \\
PEMAK & 0.60 & 0.59 \\
Rata-Rata R-Square & 0.6 & 0.42 \\
\hline
\end{tabular}

Tabel 9. Nilai Communality

\begin{tabular}{lll}
\hline \multicolumn{1}{c}{ Variabel } & \multicolumn{2}{c}{ Communality } \\
& \multicolumn{1}{c}{ Model 1 } & Model 2 \\
\hline KINF & 0.56 & 0.56 \\
KLAY & 0.67 & 0.67 \\
KPENGG & 0.71 & 0.71 \\
KSIST & 0.57 & 0.57 \\
MB & 0.76 & 0.76 \\
PEMK & 0.65 & 0.66 \\
Rata-Rata & 0.65 & 0.65 \\
Communality & & \\
\hline
\end{tabular}

Koefisien hubungan antarvariabel dilihat dari nilai koefisien korelasi (positif atau negatif) dan nilai t-statistc (jika $\geq 1,96$ maka korelasinya signifikan) seperti yang nampak pada Tabel 7 . Evaluasi Selanjutnya adalah melihat nilai $\mathrm{R}^{2}(\mathrm{R}$ Square). Nilai $\mathrm{R}$ Square penelitian ini dapat dilihat dalam Tabel 8.

\subsection{Model Gabungan}

Untuk melakukan validasi model secara keseluruhan, nilai goodness of fit (GoF) digunakan ukuran tunggal untuk validasi performa model pengukuran dan struktural yang diperoleh dari akar nilai rata-rata communality dikalikan dengan akar nilai rata-rata $\mathrm{R}$ Square (Vinzi dkk, 2010). Nilai GoF terbentang antara 0 - 1 dengan interpretasi 0,1 (GoF Kecil), 0,25 (GoF Moderat), dan 0,36 (GoF Substansial) (lihat Tabel 9).
Tabel 10. Tabel Data Tanggapan Tiap Responden

\begin{tabular}{lllllll}
\hline \multicolumn{1}{c}{ Poin } & \multicolumn{5}{c}{ Skala } \\
Pengukuran & $\mathbf{1}$ & $\mathbf{2}$ & $\mathbf{3}$ & $\mathbf{4}$ & $\mathbf{5}$ & Rerata \\
\hline KSIST3 & 1 & 21 & 42 & 37 & 9 & 3.3 \\
KSIST4 & 4 & 13 & 42 & 40 & 11 & 3.4 \\
KSIST5 & 3 & 15 & 40 & 42 & 10 & 3.4 \\
KSIST6 & 26 & 30 & 33 & 17 & 4 & 2.5 \\
KINF1 & 0 & 4 & 15 & 73 & 18 & 4.0 \\
KINF2 & 2 & 16 & 48 & 34 & 10 & 3.3 \\
KINF3 & 1 & 17 & 41 & 44 & 7 & 3.4 \\
KLAY1 & 0 & 23 & 50 & 36 & 1 & 3.1 \\
KLAY2 & 5 & 23 & 54 & 25 & 3 & 3.0 \\
KLAY3 & 4 & 28 & 55 & 21 & 2 & 2.9 \\
KLAY4 & 1 & 15 & 47 & 44 & 3 & 3.3 \\
PEMK1 & 2 & 10 & 38 & 52 & 8 & 3.5 \\
PEMK2 & 0 & 10 & 36 & 55 & 9 & 3.6 \\
PEMK3 & 0 & 4 & 17 & 67 & 22 & 4.0 \\
KPENGG1 & 0 & 10 & 27 & 53 & 20 & 3.8 \\
KPENGG2 & 2 & 14 & 42 & 48 & 4 & 3.3 \\
KPENGG3 & 0 & 15 & 45 & 45 & 5 & 3.4 \\
MB1 & 0 & 4 & 17 & 67 & 22 & 4.0 \\
MB2 & 0 & 7 & 24 & 53 & 26 & 3.9 \\
\hline
\end{tabular}

\subsection{Kesuksesan SIAKAD ITS}

Data tanggapan 110 responden yang tampak pada Tabel 10 selanjutnya digunakan untuk menentukan prosentase kesuksesan dan akan dicari nilai total rata-rata item (formula 3)

Rata-rata item pengukuran $=\frac{\sum(\text { skala } x \text { bobot skala item pengukuran })}{110}$
Rata-rata item pengukuran $=\frac{(1 \times 1)+(21 \times 2)+(42 x 3)+(37 \times 4)+(9 x 5)}{110}=3,3$

Tabel 10 juga menyajikan nilai rata-rata item pengukuran yang digunakan dalam pengukuran kesuksesan SIAKAD. Kemudian dicari bobot rata-rata item pengukuran yaitu dengan membagi total rata-rata item pengukuran dibagi banyaknya item pengukuran yang dipergunakan (19 item pengukuran) (formula 4). Nilai yang didapatkan untuk total rata-rata item pengukuran adalah 3,1. 
Utami, dkk., Analisa Kesuksesan Sistem Informasi Akademik di Perguruan Tinggi dengan...

Bobot rata-rata item pengukuran $=\frac{\text { Total rata }- \text { rata item pengukuran }}{\text { Total item pengukuran }}$

Bobot rata-rata item pengukuran $=\frac{64,8}{19}=3,1$

Langkah selanjutnya adalah mencari prosentase kesuksesan. Bobot rata-rata item pengukuran dibagi dengan banyaknya item pengukuran dibagi dengan nilai maksimal dari skala yaitu 5 kemudian dikalikan dengan $100 \%$. Pembagian tingkat kesuksesan SIAKAD ini mengadopsi penelitian Purwanto (2007) yang membagi 5 tingkatan pada kriteria kesuksesan. Berdasarkan hasil analisis yang dilakukan terhadap kesuksesan SIAKAD ITS, kesuksesan SIAKAD ITS memiliki prosentase $62 \%$ termasuk dalam tingkatan sukses (formula 5).

Prosentase Kesuksesan SIAKAD $=\frac{3,1}{5} \times 100 \%=62 \%$

\subsection{Analisis Model Pengukuran}

Hasil pengujian terhadap model pengukuran menunjukkan bahwa semua indikator mempunyai nilai $t$-statistic $\geq 1.96$. Taraf nyata $(\alpha)$ dalam penelitian ini adalah 0,05 dan nilainya didalam tabel distribusi normal adalah 1,96, artinya suatu hubungan disebut ada pengaruh apabaila t-statistic $\geq 1.96$ (Walpole dkk, 1995). Penelitian ini menggunakan nilai CA untuk mengukur reliabilitas datanya.

Pada Tabel 5 tampak hampir semua variabel mempunyai nilai $\mathrm{CA} \geq 0,6$. Pada Tabel 6 juga tampak semua variabel mengandung varian indikator yang cukup (nilai AVE > 0,5). Nilai cross loading factor tiap indikator juga telah memenuhi syarat. Dari hasil perbandingan nilai akar AVE semua variabel lebih tinggi daripada nilai korelasi antarvariabelnya, sesuai dengan yang diisyaratkan secara umum syarat kesahihan dan reliabilitas model telah terpenuhi. Sehingga dapat disimpulkan bahwa model pengukuran telah sahih dan reliabel.

\subsection{Analisis Model Struktural}

Hasil analisis terhadap model struktural (Tabel 7) menunjukkan bahwa tujuh koefisien jalur positif dan signifikan serta mendukung hipotesis $\mathrm{H} 1 \mathrm{~b}$, H2b, H3a, H3b, H4, H4b, H5a dan H5b. Sedangkan pada model 2, terdapat delapan koefisien jalur positif dan signifikan serta mendukung hipotesis H1a, H1b, H2b, H3a, H3b, H4a, H4b, dan H5b pada model 2. Dapat disimpulkan bahwa pada model 1, kualitas sistem, kualitas informasi dan kualitas layanan memiliki pengaruh positif yang signifikan terhadap kepuasan pengguna SIAKAD.
Kualitas layanan dan kepuasan pengguna juga memiliki pengaruh positif yang signifikan terhadap pemakaian SIAKAD, serta pemakaian SIAKAD dan kepuasan pengguna SIAKAD memiliki pengaruh positif yang signifikan terhadap manfaat bersih SIAKAD. Sedangkan pada model 2, kualitas sistem dan kualitas layanan memiliki pengaruh positif yang signifikan terhadap pemakaian SIAKAD.

Kualitas sistem, kualitas informasi, kualitas layanan dan pemakaian SIAKAD juga memiliki pengaruh positif yang signifikan terhadap kepuasan pengguna SIAKAD. Selain itu, pengaruh positif yang signifikan juga dimiliki oleh pemakaian SIAKAD dan kepuasan pengguna SIAKAD terhadap manfaat bersih SIAKAD.

Selain ditinjau dari sifat korelasi, analisis juga dilihat dari tingkat signifikansi pada dua model tersebut. Terdapat hubungan yang tidak signifikan antara kualitas sistem dan pemakaian SIAKAD pada model 1 penelitian dan kualitas informasi SIAKAD terhadap pemakaian SIAKAD pada kedua model penelitian. Hal ini menunjukkan ada atau tidaknya variabel kualitas sistem dan kualitas informasi hampir tidak mempengaruhi pemakaian SIAKAD. Hal ini mungkin dikarenakan fungsi sistem SIAKAD yang kurang maksimal. Peningkatan kualitas sistem SIAKAD dapat dilakukan dengan meningkatkan pertukaran informasi sesuai dengan tingkat kebutuhan pengguna SIAKAD, serta dari segi keamanan SIAKAD yang perlu ditingkatkan adalah penjaminan kerahasiaan data penggunanya.

Agar kualitas informasi SIAKAD dapat memberikan pengaruh yang cukup signifikan terhadap pemakaian SIAKAD, salah satu hal yang perlu ditingkatkan adalah meningkatkan keinformatifan SIAKAD, relevansi SIAKAD dan ketepatwaktuan informasi SIAKAD.

Pada tabel 8 tampak semua variabel endogen KPENGG, MB, dan PEMK mempunyai nilai $\mathrm{R}$ Square >0.33. Hal ini menunjukkan bahwa variabel eksogen mampu secara substansial menerangkan semua variabel endogennya.

\subsection{Analisis Model Gabungan}

Analisis terhadap keseluruhan model (model gabungan dengan melihat nilai GoF yang diperoleh dari akar rata-rata $\mathrm{R}$ Square dikalikan akar rata-rata communality. Nilai $\mathrm{GoF}=0,6$ menunjukkan model telah sesuai secara substansial dalam merepresentasikan hasil penelitian. 


\subsection{Analisa Kesuksesan SIAKAD ITS}

Kesuksesan SIAKAD ITS memiliki nilai prosentase sebesar $62 \%$. Berdasarkan penelitian yang dilakukan oleh Purwanto (2007), prosentase sebesar 62\% kesuksesan SIAKAD ITS berada pada tingkat "Sukses". Kesuksesan SIAKAD ITS pada tingkatan "Sukses" ini didukung oleh beberapa faktor kesuksesan yang ditemukan dilapangan dan hasil pengujian. Faktor-faktor pendukung kesuksesan SIAKAD ITS dapat dilihat pada Lampiran.

\section{SIMPULAN dan SARAN}

Berdasarkan pembahasan pada penelitian kesuksesan dapat disimpulkan sebagai berikut:

a. Pada model 1 terdapat hubungan yang terjadi antar variabel yaitu: Kualitas sistem, kualitas informasi dan kualitas layanan memiliki pengaruh positif yang signifikan terhadap kepuasan pengguna SIAKAD. Selain itu, kualitas layanan dan kepuasan pengguna juga memiliki pengaruh positif yang signifikan terhadap pemakaian SIAKAD. Pemakaian SIAKAD dan kepuasan pengguna SIAKAD memiliki pengaruh positif yang signifikan terhadap manfaat-manfaat bersih SIAKAD.

b. Pada model 2 juga terdapat hubungan antarvariabel yaitu: Kualitas sistem dan kualitas layanan memiliki pengaruh positif yang signifikan terhadap pemakaian SIAKAD. Kualitas sistem, kualitas informasi, kualitas layanan dan pemakaian SIAKAD juga memiliki pengaruh positif yang signifikan terhadap kepuasan pengguna SIAKAD. Pemakaian SIAKAD dan kepuasan pengguna SIAKAD memiliki pengaruh postif dan signifikan terhadap terhadap manfaatmanfaat bersih SIAKAD.

c. Berdasarkan hasil yang didapat dari pengujian model secara keseluruhan adalah diperoleh nilai $\mathrm{GoF}=0.6$, sehingga dapat disimpulkan bahwa model telah sesuai secara substansial dalam merepresentasikan hasil penelitian. Berdasarkan hasil analisis kesuksesan SIAKAD, tingkat kesuksesan SIAKAD yang digunakan di ITS Surabaya yaitu integra.ac.id adalah "Sukses" dengan prosentase kesuksesan $62 \%$.

Hasil penelitian ini tentu masih memerlukan pengujian dan penguatan lebih lanjut. saran bagi penelitian dengan topik analisis kesuksesan sistem informasi secara umum atau SIAKAD secara khusus sebagai berikut :

a. Melibatkan teori-teori dan kerangka kerja selain model kesuksesan sistem informasi Delone dan Mclean untuk menghasilkan model analisis kesuksesan SIAKAD yang lebih komprehensif. b. Mengidentifikasi variabel lain yang memiliki dasar teori yang kuat untuk dimasukkan dalam model analisis kesuksesan SIAKAD.

Berdasarkan hasil pengujian model penelitian, pada variabel kualitas sistem terdapat 2 item pengukuran yang tidak memenuhi syarat yang ditentukan dan hal ini menjadi masukan bagi penyedia layanan SIAKAD. Hal yang perlu ditingkatkan dari kualitas sistem SIAKAD supaya memenuhi kebutuhan penggunanya langsung yaitu dari segi fungsi SIAKAD, hal yang perlu ditingkatkan adalah peningkatan sistem SIAKAD sehingga dapat melakukan pertukaran informasi sesuai dengan tingkat kebutuhan pengguna SIAKAD. Segi keamanan SIAKAD yang juga perlu ditingkatkan adalah penjaminan kerahasiaan data penggunanya. Selain itu ditemukannya hubungan yang tidak signifikan antara kualitas informasi SIAKAD terhadap pemakaian SIAKAD pada kedua model penelitian. Hal ini menunjukkan ada atau tidaknya variabel kualitas informasi tidak mempengaruhi pemakaian SIAKAD. Agar kualitas informasi SIAKAD dapat memberikan pengaruh terhadap pemakaian SIAKAD, hal yang perlu ditingkatkan adalah meningkatkan keinformatifan SIAKAD, relevansi SIAKAD dan ketepatwaktuan informasi SIAKAD.

\section{DAFTAR RUJUKAN}

Abugabah, Ahed., Sanzogni, Louis., 2010, Reconceptualizing Information Systems Models: An Experience from ERP Systems Environment, International Journal for Infonomics (IJI), Volume 3, Issue 4.

Barki, H., and Hartwick, J., 1994, Measuring User Participation, User Involevement, and User Attitude. MIS Quarterly.

Delone, W.H. and Mclean, ER.,1992, Information System Success ; The Quest For The Dependent Variable, Information System Research, March 1992

Delone, W.H. \& Mclean, E.R., 2003, "The Delone and Mclean Model of Information Systems Success: A ten-Year Update". Journal of Management Information Systems. Vol. 19 (4). Pp. 9 - 30. M.E. Sharpe, Inc.

Goodhue, D. L. and Thompson, R. L. 1995. Task-technology fit and individual performance. MIS Quarterly.

Jogiyanto, 2007. Sistem Informasi Keperilakuan. Edisi Revisi. Yogyakarta: Penerbit Andi

Purwanto, Ari, 2007, Rancangan dan Implementasi Model Pemeriksaan Kinerja 
Utami, dkk., Analisa Kesuksesan Sistem Informasi Akademik di Perguruan Tinggi dengan...

Badan Pemeriksa Keuangan Republik Indonesia Atas Aplikasi E-Government di Pemerintah Daerah: Studi Kasus Kabupaten Sragen. Tesis Program Pasca Sarjana Universitas Gajah Mada. Yogyakarta.

Rai, A., Lang, S.S. and Welker, R.B. 2002. Assessing the Validity of IS Success Models: An Empirical Test and Theoretical Analysis, Information System Research, Vol.13 (1): 29-34

Sumadi, 2010, Sikap Dan Perilaku Dosen Serta Mahasiswa Terhadap Implementasi Sistem Informasi Administrasi Akademik Online (Studi kasus Di Universitas Negeri Lampung), JPP Volume 8, Nomor 1.

Suwanto, Raharjo, Edhy, Sutanta, Ema, Utami, 2007, Analisis Aspek-Aspek Kualitas Schema Database (Studi Kasus Pada Database Akademik Ista Yogyakarta), SNATI, Yogyakarta, ISSN 1978-9777.

Sugiyono, 2009, Metode Penelitian Kuantitatif, Kualitatif dan $R \& D$, Alfabeta, Bandung.

Tanuwijaya, Haryanto dan Sarno, Riyanarto 2010, Comparation of CobiT Maturity Model and Structural Equation Model for Measuring the Alignment between University Academic Regulations and Information Technology Goals International Journal of Computer Science and Network Security, Vol.10 No.6.

Wangpipatwong, Sivaporn; Chutimaskul, Wichian; \& Papasratorn, Borworn. 2005. Factors Influencing the Adoption of Thai eGovernment Websites: Information Quality and System Quality Approach . Prosiding dari the 4 th International Conference on eBusiness. $19-20$ November. Bangkok, Thailand. Pp. 14.1 - 14.7

Weber, Ron., 1999, Information Systems Control and Audit, Prentice-Hall, Inc.New Jersey, Amerika Serikat.

Yamin,S.\& Kurniawan, H. 2009, Structural Equation Modelling: Belajar Lebih Mudah Teknik Analisis Data Kuesioner dengan Lisrel-PLS, Buku Aplikasi Statistik Seri 2, Salemba Infotek, ISBN 978-602-8126-08-3.

\section{LAMPIRAN}

Faktor Pendukung Kesuksesan SIAKAD ITS

\begin{tabular}{|c|c|}
\hline $\begin{array}{c}\text { Item } \\
\text { pengukuran }\end{array}$ & Faktor kesuksesan \\
\hline \multirow{4}{*}{$\begin{array}{l}\text { Fungsi } \\
\text { SIAKAD }\end{array}$} & $\begin{array}{l}\text { SIAKAD dapat mencetak transkri, KHS } \\
\text { dan FRS }\end{array}$ \\
\hline & $\begin{array}{l}\text { SIAKAD menyediakan FRS dan dapat } \\
\text { mempermudah konsultasi rencana study } \\
\text { secara online. }\end{array}$ \\
\hline & $\begin{array}{l}\text { SIAKAD terintegrasi dengan sistem } \\
\text { yang lain sehingga mempermudah } \\
\text { melihat informasi terkait dengan } \\
\text { kebutuhan pengguna }\end{array}$ \\
\hline & $\begin{array}{l}\text { SIAKAD dapt digunakan untuk } \\
\text { meningkatkan mutu dan kualitas } \\
\text { pembelajaran (kuesioner penilaian } \\
\text { kinerja dosen dan matakuliah) }\end{array}$ \\
\hline \multirow{4}{*}{$\begin{array}{l}\text { Keamanan } \\
\text { SIAKAD }\end{array}$} & $\begin{array}{l}\text { Tersedia kebijakan penggantian } \\
\text { password oleh pengguna sehingga tidak } \\
\text { mudah di hack oleh orang yang tidak } \\
\text { bertanggung jawab }\end{array}$ \\
\hline & $\begin{array}{l}\text { SIAKAD ITS dapat mengidentifikasi } \\
\text { penggunanya melalui username dan } \\
\text { password serta dapat melakukan } \\
\text { autentifikasi }\end{array}$ \\
\hline & $\begin{array}{l}\text { SIAKAD dapat melakukan proses } \\
\text { otorisasi }\end{array}$ \\
\hline & $\begin{array}{l}\text { SIAKAD memiliki mekanisme untuk } \\
\text { memastikan pengiriman informasi } \\
\text { pengguna dengan aman. }\end{array}$ \\
\hline \multirow{4}{*}{$\begin{array}{l}\text { Performansi } \\
\text { SIAKAD }\end{array}$} & $\begin{array}{l}\text { SIAKAD mudah diakses setiap saat } \\
\text { (tersedia } 1 \times 24 \text { jam) }\end{array}$ \\
\hline & $\begin{array}{l}\text { Maksimal kegagalan sistem terjadi }<1 \\
\text { minggu }\end{array}$ \\
\hline & $\begin{array}{l}\text { Proses error recovery yang cepat dari } \\
\text { sistem SIAKAD }\end{array}$ \\
\hline & $\begin{array}{l}\text { Akses cepat dalam memilih menu pada } \\
\text { link-link di SIAKAD serta cepat dalam } \\
\text { mendownload data. }\end{array}$ \\
\hline \multirow{5}{*}{$\begin{array}{l}\text { Kemudahan } \\
\text { Penggunaan } \\
\text { SIAKAD }\end{array}$} & $\begin{array}{l}\text { SIAKAD mudah diakses, tatacara regis- } \\
\text { trasi akademik tidak rumit, proses login } \\
\text { tidak menyusahkan serta pengoperasian } \\
\text { sistem SIAKAD mudah dapat } \\
\text { dilakukan tanpa bimbingan. }\end{array}$ \\
\hline & $\begin{array}{l}\text { Cara penggunaan SIAKAD mudah } \\
\text { dipelajari dan tampilan } u \text { ser fiendly }\end{array}$ \\
\hline & SIAKAD tidak membutuhkan software \\
\hline & $\begin{array}{l}\text { khusus yang harus diinstall di komputer } \\
\text { pengguna bila hendak menggunakan- } \\
\text { nya, hal ini dikarenakan SIAKAD } \\
\text { sudah berbasis Web }\end{array}$ \\
\hline & $\begin{array}{l}\text { Kemudahan penggunaan SIAKAD ITS } \\
\text { menghemat waktu dan mempermudah } \\
\text { kegiatan seperti mempermudah peman- } \\
\text { tauan nilai-nilai dan kegiatan akademik } \\
\text { secara online }\end{array}$ \\
\hline \multirow{4}{*}{$\begin{array}{l}\text { Jarak Akses } \\
\text { SIAKAD }\end{array}$} & $\begin{array}{l}\text { SIAKAD dapat diakses di semua } \\
\text { jurusan dan fakultas }\end{array}$ \\
\hline & $\begin{array}{l}\text { SIAKAD dapat diakses di semua } \\
\text { fakultas }\end{array}$ \\
\hline & $\begin{array}{l}\text { SIAKAD dapat diakses di daerah } \\
\text { sekitar/lingkungan kampus }\end{array}$ \\
\hline & $\begin{array}{l}\text { SIAKAD dapat diakses di tempat } \\
\text { tinggal sementara pengguna }\end{array}$ \\
\hline \multirow{4}{*}{$\begin{array}{l}\text { Kesesuaian } \\
\text { SIAKAD } \\
\text { dengan } \\
\text { peramban dan } \\
\text { peralatan } \\
\text { teknologi }\end{array}$} & $\begin{array}{l}\text { SIAKAD dapat diakses menggunakan } \\
\text { web peramban Mozilla Firefox }\end{array}$ \\
\hline & $\begin{array}{l}\text { SIAKAD dapat diakses menggunakan } \\
\text { web peramban internet explorer }\end{array}$ \\
\hline & $\begin{array}{l}\text { SIAKAD dapat diakses menggunakan } \\
\text { web peramban Google Chrome }\end{array}$ \\
\hline & $\begin{array}{l}\text { Selain dengan komputer yang } \\
\text { terkoneksi dengan jaringan internet, }\end{array}$ \\
\hline
\end{tabular}




\begin{tabular}{|c|c|}
\hline & $\begin{array}{l}\text { pengguna SIAKAD (mahasiswa,dosen } \\
\text { dan staff) dapat mengakses SIAKAD } \\
\text { dengan handphone/peralatan gadget } \\
\text { lainnya yang juga terkoneksi dengan } \\
\text { jaringan internet. }\end{array}$ \\
\hline \multirow{4}{*}{$\begin{array}{l}\text { Keinformatifan } \\
\text { SIAKAD }\end{array}$} & $\begin{array}{l}\text { SIAKAD sangat informatif dalam } \\
\text { memberikan jadwal perkuliahan }\end{array}$ \\
\hline & $\begin{array}{l}\text { SIAKAD sangat informatif dalam } \\
\text { memberikan layanan FRS Online }\end{array}$ \\
\hline & $\begin{array}{l}\text { SIAKAD sangat informatif dalam } \\
\text { memberikan informasi seputar } \\
\text { perwalian mahasiswa (persetujuan FRS } \\
\text { oleh dosen wali) }\end{array}$ \\
\hline & $\begin{array}{l}\text { SIAKAD sangat informatif dalam } \\
\text { memberikan informasi nilai, IPK } \\
\text { (Indeks Prestasi Kumulatif) mahasiswa } \\
\text { dan IPS (Indeks Prestasi Semester) } \\
\text { mahasiswa. }\end{array}$ \\
\hline \multirow{4}{*}{$\begin{array}{l}\text { Relevansi } \\
\text { SIAKAD }\end{array}$} & $\begin{array}{l}\text { SIAKAD bermanfaat untuk } \\
\text { meningkatkan dan memudahkan } \\
\text { informasi akademik tidak hanya bagi } \\
\text { mahasiswa tetapi juga sangat penting } \\
\text { bagi dosen maupun staf akademik non } \\
\text { edukasi. }\end{array}$ \\
\hline & $\begin{array}{l}\text { SIAKAD bermanfaat dalam melakukan } \\
\text { ploting mata kuliah (mata kuliah, hari } \\
\text { dan jam yang bisa langsung) serta dapat } \\
\text { memberikan kesempatan kepada } \\
\text { mahasiswa langsusng memilih kelas } \\
\text { perkuliahan }\end{array}$ \\
\hline & $\begin{array}{l}\text { SIAKAD ITS bermanfaat untuk } \\
\text { memudahkan pemantauan nilai, baik } \\
\text { melalui histori nilai, rekapitulasi nilai, } \\
\text { maupun laporan kemajuan akademik }\end{array}$ \\
\hline & $\begin{array}{l}\text { SIAKAD ITS bermanfaat dalam } \\
\text { mengefektifkan perwalian yang } \\
\text { dilakukan oleh mahasiswa dengan } \\
\text { dosen walinya. }\end{array}$ \\
\hline \multirow{4}{*}{$\begin{array}{l}\text { Ketepatwaktuan } \\
\text { informasi }\end{array}$} & $\begin{array}{l}\text { Penayangan/pemunculan data akademis } \\
\text { seca-ra online melalui internet tepat } \\
\text { waktu }\end{array}$ \\
\hline & $\begin{array}{l}\text { Penanganan yang cepat dan tepat waktu } \\
\text { bila terjadi perubahan pada data } \\
\text { akademik, misalkan terjadi perubahan } \\
\text { data yang dilakukan oleh Dosen, data } \\
\text { tersebut bisa langsung ter-update }\end{array}$ \\
\hline & $\begin{array}{l}\text { SIAKAD mendukung penyediaan } \\
\text { informasi untuk pengambilan keputusan } \\
\text { yang bersifat cepat. }\end{array}$ \\
\hline & $\begin{array}{l}\text { SIAKAD selalu dapat menyediakan } \\
\text { informasi pada saat yang diperlukan } \\
\text { oleh pengguna }\end{array}$ \\
\hline \multirow{4}{*}{$\begin{array}{l}\text { Kehandalan } \\
\text { Layanan } \\
\text { SIAKAD }\end{array}$} & $\begin{array}{l}\text { Layanan SIAKAD mendokumentasikan } \\
\text { data-data kegiatan akademik mahasiswa } \\
\text { dengan baik. }\end{array}$ \\
\hline & $\begin{array}{l}\text { Petugas sangat berhati-hati dan teliti } \\
\text { dalam menginputkan data } \\
\text { kemahasiswaan (memasukkan nilai dan } \\
\text { jadwal). }\end{array}$ \\
\hline & $\begin{array}{l}\text { Petugas segera memberikan } \\
\text { penyelesaian dengan tepat apabila } \\
\text { terjadi kesalahan terkait dengan layanan } \\
\text { yang diberikan oleh SIAKAD (dalam } \\
\text { penyajian data dan informasi dalam } \\
\text { SIAKAD). }\end{array}$ \\
\hline & $\begin{array}{l}\text { Petugas layanan SIAKAD segera } \\
\text { memperbaiki apabila terjadi gangguan } \\
\text { sistem pada server. }\end{array}$ \\
\hline \multirow{3}{*}{$\begin{array}{l}\text { Jarak Akses } \\
\text { SIAKAD }\end{array}$} & $\begin{array}{l}\text { SIAKAD dapat diakses di semua } \\
\text { jurusan dan fakultas }\end{array}$ \\
\hline & $\begin{array}{l}\text { Petugas memberikan informasi secara } \\
\text { jelas terkait informasi yang dibutuhkan } \\
\text { oleh pengguna SIAKAD }\end{array}$ \\
\hline & Selain melakukan pelayanan tatap \\
\hline
\end{tabular}

\begin{tabular}{|c|c|}
\hline & $\begin{array}{l}\text { muka, petugas juga melakukan } \\
\text { pelayanan via telepon dan juga } \\
\text { pelayanan via email }\end{array}$ \\
\hline & $\begin{array}{l}\text { Petugas memahami kebutuhan dari } \\
\text { setiap pengguna SIAKAD serta petugas } \\
\text { memahami permasalahan yang dihadapi } \\
\text { oleh pengguna. }\end{array}$ \\
\hline \multirow{4}{*}{$\begin{array}{l}\text { Jaminan } \\
\text { Layanan } \\
\text { SIAKAD }\end{array}$} & $\begin{array}{l}\text { Layanan SIAKAD memberikan } \\
\text { jaminan yaitu petugas memberitahu } \\
\text { waktu yang pasti dari penyelesaian } \\
\text { setiap tahapan pengurusan SIAKAD }\end{array}$ \\
\hline & $\begin{array}{l}\text { Layanan SIAKAD memberikan } \\
\text { jaminan yaitu petugas menyelesaikan } \\
\text { permasalahan tentang SIAKAD ITS } \\
\text { sesuai dengan waktu yang dijanjikan }\end{array}$ \\
\hline & $\begin{array}{l}\text { Petugas menjamin komplain terkait } \\
\text { SIAKAD dapat diselesaikan dengan } \\
\text { tidak terbelit-belit }\end{array}$ \\
\hline & $\begin{array}{l}\text { Layanan SIAKAD menjamin layanan } \\
\text { SIAKAD online memudahkan } \\
\text { mahasiswa dalam mengisi FRS }\end{array}$ \\
\hline \multirow{4}{*}{$\begin{array}{l}\text { Empati layanan } \\
\text { SIAKAD }\end{array}$} & $\begin{array}{l}\text { Layanan SIAKAD mengetahui dan } \\
\text { mengerti bahwa pengguna SIAKAD } \\
\text { menginginkan tersedianya sarana } \\
\text { penunjang teknologi informasi di ITS } \\
\text { untuk dapat mengakses SIAKAD }\end{array}$ \\
\hline & $\begin{array}{l}\text { Layanan SIAKAD ITS mengetahui dan } \\
\text { mengerti bahwa pengguna SIAKAD } \\
\text { menginginkan biaya yang lebih murah } \\
\text { terkait dengan adanya SIAKAD Online } \\
\text { (dalam mencetak KRS maupun } \\
\text { KHS,dll) }\end{array}$ \\
\hline & $\begin{array}{l}\text { Layanan SIAKAD ITS mengetahui dan } \\
\text { mengerti bahwa pengguna SIAKAD } \\
\text { menginginkan SIAKAD online lebih } \\
\text { cepat dibandingkan layanan SIAKAD } \\
\text { secara manual (biasa), sehingga dapat } \\
\text { menghemat waktu penggunanya }\end{array}$ \\
\hline & $\begin{array}{l}\text { Layanan SIAKAD ITS mengetahui dan } \\
\text { mengerti bahwa pengguna SIAKAD } \\
\text { menginginkan pembaharuan data } \\
\text { akademik yang ada di sistem informasi } \\
\text { akademik sehingga } u \text { ser/pengguna } \\
\text { dapat memastikan adanya informasi } \\
\text { terbaru }\end{array}$ \\
\hline \multirow{4}{*}{$\begin{array}{l}\text { Frekuensi } \\
\text { Penggunaan } \\
\text { SIAKAD }\end{array}$} & sekali atau dua kali dalam satu bulan \\
\hline & sekali atau dua kali dalam 15 hari \\
\hline & sekali atau dua kali dalam seminggu \\
\hline & sekali dalam satu hari \\
\hline \multirow{4}{*}{$\begin{array}{l}\text { Durasi waktu } \\
\text { Penggunaan } \\
\text { SIAKAD }\end{array}$} & 5-10 menit \\
\hline & $10-20$ menit \\
\hline & 20-30 menit \\
\hline & Lebih dari 30 menit \\
\hline \multirow[b]{3}{*}{$\begin{array}{l}\text { Penggunaan } \\
\text { Nyata SIAKAD }\end{array}$} & $\begin{array}{l}\text { Pengisian KRS oleh mahasiswa dan } \\
\text { dosen wali/pembimbing akademik } \\
\text { memberikan persetujuan terhadap KRS } \\
\text { mahasiswa melalui SIAKAD }\end{array}$ \\
\hline & $\begin{array}{l}\text { SIAKAD digunakan untuk pengisian } \\
\text { nilai matakuliah secara online oleh } \\
\text { dosen pengampu matakuliah dan dapat } \\
\text { digunakan untuk melihat nilai } \\
\text { matakuliah,IPK dan IPS oleh } \\
\text { mahasiswa maupun staff akademik } \\
\end{array}$ \\
\hline & $\begin{array}{l}\text { SIAKAD digunakan untuk pengisian } \\
\text { kuesioner pada setiap akhir semester } \\
\text { sebagai penilaian untuk tolak ukur } \\
\text { peningkatan kualitas belajar mengajar. } \\
\text { Penilaian kuesioner di dasarkan pada } \\
\text { matakuliah yang diambil oleh } \\
\text { mahasiswa yang bersangkutan. Selain } \\
\text { itu, penilaian ini juga sebagai bahan } \\
\text { evalusi pihak akademik dan jurusan } \\
\text { untuk dosen yang mengajar matakuliah } \\
\text { tertentu }\end{array}$ \\
\hline
\end{tabular}


Utami, dkk., Analisa Kesuksesan Sistem Informasi Akademik di Perguruan Tinggi dengan...

\begin{tabular}{|c|c|}
\hline & $\begin{array}{l}\text { SIAKAD dapat digunakan untuk } \\
\text { mencetak KHS dan transkrip oleh } \\
\text { mahasiswa maupun staff akademik, } \\
\text { serta dapat digunakan untuk mencari } \\
\text { informasi akademik lainnya (biodata } \\
\text { mahasiswa, status mahasiswa, kuriku- } \\
\text { lum semester, transaksi pembayaran } \\
\text { terkait akademik mahasiswa) baik oleh } \\
\text { mahasiswa, dosen maupun staff } \\
\text { akademik terkait dengan akademik } \\
\text { mahasiswa }\end{array}$ \\
\hline \multirow{4}{*}{$\begin{array}{l}\text { Keakuratan } \\
\text { SIAKAD }\end{array}$} & $\begin{array}{l}\text { SIAKAD menyediakan data yang } \\
\text { sesuai dengan kegiatan akademik yang } \\
\text { dijalankan }\end{array}$ \\
\hline & $\begin{array}{l}\text { SIAKAD menghasilkan data akademik } \\
\text { yang tepat dan lengkap bagi } \\
\text { penggunanya (data mahasiswa, data } \\
\text { nilai, data KRS, data IPK/IPS, data } \\
\text { perkuliahan, data history status } \\
\text { mahasiswa) }\end{array}$ \\
\hline & $\begin{array}{l}\text { SIAKAD menghasilkan data akademik } \\
\text { yang mengandung kebenaran yaitu } \\
\text { sesuai dengan perhitungan-perhitungan } \\
\text { yang ada dalam proses tersebut }\end{array}$ \\
\hline & $\begin{array}{l}\text { SIAKAD menghasilkan informasi yang } \\
\text { dapat memberikan kesimpulan yang } \\
\text { sama dari berbagai pengguna/pemakai } \\
\text { sistem informasi akademik }\end{array}$ \\
\hline \multirow{10}{*}{$\begin{array}{l}\text { Kelengkapan } \\
\text { Isi/Modul } \\
\text { SIAKAD }\end{array}$} & Modul Data mahasiswa \\
\hline & Modul FRS \\
\hline & Modul Nilai \\
\hline & Modul Penilaian Kinerja Dosen \\
\hline & Modul Penilaian Matakuliah \\
\hline & Modul Status Mahasiswa \\
\hline & Modul Transkrip \\
\hline & Modul Kurikulum Semester \\
\hline & Modul Tugas Akhir \\
\hline & Modul Matakuliah Prasyarat \\
\hline \multirow{2}{*}{$\begin{array}{l}\text { Format } \\
\text { Penyajian } \\
\text { Informasi } \\
\text { SIAKAD }\end{array}$} & $\begin{array}{l}\text { Informasi yang disajikan SIAKAD jelas } \\
\text { untuk dimengerti dengan menggunakan } \\
\text { bahasa yang mudah dipahami oleh } \\
\text { pengguna }\end{array}$ \\
\hline & $\begin{array}{l}\text { SIAKAD menyajikan informasi nilai } \\
\text { dalam bentuk angka maupun huruf } \\
\text { secara jelas }\end{array}$ \\
\hline $\begin{array}{c}\text { Format } \\
\text { Penyajian }\end{array}$ & $\begin{array}{l}\text { Informasi yang disajikan SIAKAD jelas } \\
\text { untuk dimengerti dengan menggunakan }\end{array}$ \\
\hline
\end{tabular}

\begin{tabular}{|c|c|}
\hline $\begin{array}{l}\text { Informasi } \\
\text { SIAKAD }\end{array}$ & $\begin{array}{l}\text { bahasa yang mudah dipahami oleh } \\
\text { pengguna }\end{array}$ \\
\hline \multirow{3}{*}{$\begin{array}{l}\text { Durasi waktu } \\
\text { Penggunaan } \\
\text { SIAKAD }\end{array}$} & $\begin{array}{l}\text { SIAKAD menyajikan informasi nilai } \\
\text { dalam bentuk angka maupun huruf } \\
\text { secara jelas }\end{array}$ \\
\hline & $\begin{array}{l}\text { SIAKAD menyajikan informasi ke } \\
\text { dalam format tabel sehingga } \\
\text { memudahkan penggunanya untuk } \\
\text { membacanya dan dalam mengambil } \\
\text { kesimpulan maupun keputusan }\end{array}$ \\
\hline & $\begin{array}{l}\text { SIAKAD menyajikan informasi } \\
\text { perkembangan IPK dan IPS mahasiswa } \\
\text { untuk tiap semesternya dalam bentuk } \\
\text { format yang mudah dipahami oleh } \\
\text { pengguna }\end{array}$ \\
\hline $\begin{array}{l}\text { Peningkatan } \\
\text { Produktivitas } \\
\text { Kinerja } \\
\text { Individu } \\
\end{array}$ & $\begin{array}{l}\text { Mahasiswa, baik mahasiswa KP (Kerja } \\
\text { Praktek) dapat melakukan pengisian } \\
\text { KRS dimana saja sehingga tidak harus } \\
\text { melakukannya di kampus }\end{array}$ \\
\hline \multirow{4}{*}{$\begin{array}{l}\text { Penggunaan } \\
\text { Nyata SIAKAD } \\
\text { Efektivitas } \\
\text { Organisasi }\end{array}$} & $\begin{array}{l}\text { Dosen dapat dengan cepat dalam hal } \\
\text { pengisian nilai matakuliah }\end{array}$ \\
\hline & $\begin{array}{l}\text { Dosen pembimbing akademik dapat } \\
\text { langsung memberikan persetujuan } \\
\text { terhadap KRS mahasi swa yang menjadi } \\
\text { walinya }\end{array}$ \\
\hline & $\begin{array}{l}\text { Pihak staf akademik jurusan dapat cepat } \\
\text { melakukan pengaturan jadwal kuliah } \\
\text { dari pengaturan matakuliah, jam, } \\
\text { tempat, mahasiswa sebagai } \\
\text { pengikut/peserta matakuliah dan dosen } \\
\text { pengampu matakuliah. }\end{array}$ \\
\hline & $\begin{array}{l}\text { Dengan adanya SIAKAD online dapat } \\
\text { mengefektifkan pengisian FRS oleh } \\
\text { mahasiswa, sehingga menghemat waktu } \\
\text { mahasiswa dalam melakukan FRS }\end{array}$ \\
\hline \multirow{3}{*}{$\begin{array}{l}\text { Keakuratan } \\
\text { SIAKAD }\end{array}$} & $\begin{array}{l}\text { Dengan adanya SIAKAD online dapat } \\
\text { mengefektifkan dalam pengisian nilai } \\
\text { matakuliah oleh dosen }\end{array}$ \\
\hline & $\begin{array}{l}\text { Dengan adanya SIAKAD online dapat } \\
\text { mengefektifkan waktu dalam hal } \\
\text { pengaturan jadwal kuliah sehingga } \\
\text { tidak terjadi crash. }\end{array}$ \\
\hline & $\begin{array}{l}\text { Dengan adanya SIAKAD online dapat } \\
\text { mengefektifkan pencarian informasi } \\
\text { terkait akademik mahasiswa baik oleh } \\
\text { mahasiswa, dosen maupun staff }\end{array}$ \\
\hline
\end{tabular}

